\title{
MAINTENANCE OF SCORPIONS OF THE GENUS Tityus KOCH (SCORPIONES, BUTHIDAE) FOR VENOM OBTENTION AT INSTITUTO BUTANTAN, SÃO PAULO, BRAZIL.
}

\author{
CANDIDO D. M. ${ }^{1}$; LUCAS S. ${ }^{1}$ \\ ${ }^{1}$ Laboratório de Artrópodes, Instituto Butantan
}

\begin{abstract}
This work presents the experience of the Laboratory of Arthropods at Instituto Butantan, which maintains scorpions in captivity in order to obtain the venom used in the production of anti-arachnid serum. Between 1993 and 2000, the laboratory received 24.781 specimens of Tityus serrulatus in order to obtain poison for the production of anti-scorpion serum. In the first extraction, performed by electrical stimulation, the animals gave an average quantity of $0.4 \mathrm{mg}$ venom per specimen. Animal acquisition and involved professional safety are considered. In addition, the captivity, handling and feeding techniques are described, as well as the method and equipment used for venom extraction. It shows the importance of regular campaigns, offering information to the general population in order to motivate these to catch and send alive scorpions to the Institute to assuring a regular entrance of scorpions.
\end{abstract}

KEYWORDS: scorpions, Tityus, maintenance, venom.

\section{CORRESPONDENCE TO:}

D. M. Candido - Laboratório de Artrópodes, Instituto Butantan, Avenida Vital Brazil, 1500, Butantã, São Paulo, 05503-900, São Paulo, Brasil.

E-mail: denisecandido@butantan.gov.br 
D. M. Candido; S. Lucas. MAINTENANCE OF SCORPIONS OF THE GENUS Tityus KOCH (SCORPIONES, BUTHIDAE) FOR VENOM OBTENTION AT INSTITUTO BUTANTAN, SÃO PAULO, BRAZIL. J. Venom. Anim. Toxins incl. Trop. Dis., 2004, 10, 1, p.87.

\section{INTRODUCTION}

The first anti-scorpion serum, which is produced in industrial scale in Brazil, was elaborated by Vital Brazil (2), at Instituto Butantan in 1917, using Maurano's methodology (6).

Macerated vesicles of scorpions were used in the elaboration of the serum against scorpions of the Tityus serrulatus and Tityus bahiensis species. For this serum evaluation, Vital Brazil used the pure venom obtained from mechanically excited live animals. The limiting factor for serum production had always been the difficulty in obtaining enough scorpions for the extraction. This problem was partially solved when Vital Brazil trained professionals to collect scorpions and sent them to the Institute, as he had commented in his annual reports.

Since 1953, Bücherl, as the head of the Laboratory of Arthropods, had always been worrying about the quality of the serum produced, which had a very low immunogenical capacity. He reported his experience in keeping alive animals in captivity and developed a safer methodology to handle the animals. He also introduced the use of equipment, which enables pure venom extraction by electrical stimulation (3). He presented the first data about average, the minimum and maximum quantities of venom produced by two species, Tityus bahiensis and Tityus serrulatus (4).

Animal acquisition has been doing by professionals, and the cooperation of Felisberto Miguel Arcanjo, from Mato Dentro, Minas Gerais is remarkable, he sent almost 8.000 live Tityus serrulatus specimens every year until 1990.

The maintenance of such large quantities of animals in captivity showed several problems like: the excess of animals in each cage, not regular and not enough feeds, the difficulties in cleaning the cages and other problems. Consequently, the survival of the animals normally did not exceed the first venom extraction.

The venom obtained from these animals was vacuum dried and used as raw material for the serum production. Over the years, the maintenance of the animals was improved. 
D. M. Candido; S. Lucas. MAINTENANCE OF SCORPIONS OF THE GENUS Tityus KOCH (SCORPIONES, BUTHIDAE) FOR VENOM OBTENTION AT INSTITUTO BUTANTAN, SÃO PAULO, BRAZIL. J. Venom. Anim. Toxins incl. Trop. Dis., 2004, 10, 1, p.88.

In 1995, the Laboratory opened a new area exclusively to keep alive animals. Controlled handling and more appropriate maintenance of the scorpions allowed higher survival rates, and a better yield of venom were obtained, providing the needs of Institute.

\section{MATERIAL AND METHODS}

\section{Animal Acquisition}

Since 1990, due to the growing difficulties in acquiring scorpions from private suppliers, campaigns were made, supported by the SUCEN (Superintendência do Controle de Endemias - Health Department), and city halls.

Pamphlets with information on scorpion biology were distributed, encouraging the capture of alive animals and the method to deliver them to the city halls, which were in responsible for their transportation to the Institute. In 1994, a campaign was accomplished all over the São Paulo State and a "Manual de Diretrizes para Atividades de Controle do Escorpião" was edited (7). This campaign aimed to reach the locations with high levels of scorpion incidence. Therefore, associated to other factors of stimulus such as: courses, lectures, personal contact and interchanges among institutions, there was an expressive increase in the acquisition of animals, as shown in Table 1. We must remember the animals are characteristically seasonal (5), being found more frequently among the months from December to April. Campaigns did not always reflect this seasonal variation, as they depend on different factors such as the availability of a collecting team, and facility of transport. In addition, campaigns need to be periodically reinforced in order to guarantee a continuous supply of animals.

Table1. Number of Tityus serrulatus received by the Laboratory.

\begin{tabular}{l|l|l|l|l|l|l|l}
\hline $\mathbf{1 9 9 3}$ & $\mathbf{1 9 9 4}$ & $\mathbf{1 9 9 5}$ & $\mathbf{1 9 9 6}$ & $\mathbf{1 9 9 7}$ & $\mathbf{1 9 9 8}$ & $\mathbf{1 9 9 9}$ & $\mathbf{2 0 0 0}$ \\
\hline 2897 & 3323 & 4284 & 2559 & 2432 & 3248 & 2926 & 3112 \\
\hline
\end{tabular}


D. M. Candido; S. Lucas. MAINTENANCE OF SCORPIONS OF THE GENUS Tityus KOCH (SCORPIONES, BUTHIDAE) FOR VENOM OBTENTION AT INSTITUTO BUTANTAN, SÃO PAULO, BRAZIL. J. Venom. Anim. Toxins incl. Trop. Dis., 2004, 10, 1, p.89.

\section{Bioterium of Scorpions}

The bioterium of the Laboratory of Arthropods at Instituto Butantan was inaugurated in March, 1995. It consists of four different areas covering $200 \mathrm{~m}^{2}$ designed to keeping spiders, scorpions, and insects. All rooms are equipped with several windows that provide natural ventilation; heaters are turned on during colder months to maintain the temperature between $23-25^{\circ} \mathrm{C}$. Scorpions are kept in one room of $12 \mathrm{~m}^{2}$ with two windows; Tityus serrulatus, Tityus bahiensis, and small quantities of other species are kept there (figure 1).

The animals, which arrive in the bioterium, are identified and selected: adult specimens, ready for venom extraction, are accommodated in appropriate cages according to first, second, third extraction, etc. All the activities are supervised and controlled by a professional in order to obtaining satisfactory results.

The quantity of animals maintained in the bioterium depends on the number received over the year, and it must be sufficient to requested venom demand.

An animal can remain in the laboratory for approximately 18 months. After this period, if there are enough animals to guarantee the venom production, the specimen will be sacrificed because its yield is very low.

Birth of young in the captivity is common. If there is a possibility of raising them, it is necessary to isolate the females and their progeny, and then the young from the mother. Raising large quantities of young under laboratory conditions is difficult because it requires more space, enough food, and quantity of skilled professionals.

Right now, the animals used in the venom production are kept in 13 different cages, two of them are designed to receive new animals that remain isolated for about 30 days. After the first venom extraction, they are definitely introduced in the production. In order to maintain a productivity control, the animals from different extractions are never mixed.

The cage measure are $50 \mathrm{~W} \times 75 \mathrm{~L} \mathrm{X} \mathrm{40H} \mathrm{cm}$, made of light colored polyethylene for easy visual monitoring. Commercially available boxes have rough corners enabling animals to escaping. To avoid this, the corners are covered with plastic adhesive tape. 
D. M. Candido; S. Lucas. MAINTENANCE OF SCORPIONS OF THE GENUS Tityus KOCH (SCORPIONES, BUTHIDAE) FOR VENOM OBTENTION AT INSTITUTO BUTANTAN, SÃO PAULO, BRAZIL. J. Venom. Anim. Toxins incl. Trop. Dis., 2004, 10, 1, p.90.

Instituto Butantan's cages accommodate no more than 300 animals, which are handled with an anatomical metal tongs, measuring between 20 and $30 \mathrm{~cm}$ in length. The cage floor is covered with a plate of waved cardboard to offering comfort to the animals and avoid their stress. Layers of waved cardboard, overlaid and folded in accordion shape, increase the surface area and avoid excessive contact among the animals, preventing frequent cannibalism. Cardboard offers appropriate protective, ever since the scorpions show a high night activity. It is an extremely light material, avoiding wound to the animals during handling. It is cheap and easy to find in the market. Water is supplied in 3 X 29 X $17 \mathrm{~cm}$ plastic bowls (one in each cage), containing wet cotton (figures 2,3 ). The cages are placed on iron shelves and covered with net lids framed with wood; they are labeled accordingly. A control file is kept beside each cage and data such as entrance date, feeding, extraction and death are registered. Maintenance is weekly, and includes change of cotton and cardboard, removal of dead animals and wash of each one of the boxes with water and neutral soap. Daily handling must be avoided in order to decreasing animal stress.

Other substrates such as earth, sand, bricks, and roof tile were experimentally used to imitate the natural habitat, but several problems occurred. Not only it was extremely difficult to maintain the cages clean, but also the excess of weight caused wounds to the animals and increased the risk of accidents since the objects had to be removed from the cage by hand. Newspaper must be avoided, because its ink intoxicates the animals.

\section{Feeding}

The Laboratory of Arthropods maintains several kinds of insects to feed all the animals in the bioterium.

Food is offered to the scorpions once a week, after venom extraction, consisting of Gryllus sp., Periplaneta americana, or Pycnocellus sp. The insects are kept in the cages for two days and then the cleaning is performed, removing all animals, washing the cages with water and neutral soap, and changing cotton and cardboard. 
D. M. Candido; S. Lucas. MAINTENANCE OF SCORPIONS OF THE GENUS Tityus KOCH (SCORPIONES, BUTHIDAE) FOR VENOM OBTENTION AT INSTITUTO BUTANTAN, SÃO PAULO, BRAZIL. J. Venom. Anim. Toxins incl. Trop. Dis., 2004, 10, 1, p.91.

Feeding follows a chronogram. Every week, specimens from two or three cages are fed according to the food availability, assuring that each cage receives food at least every 40 to 50 days. Experience demonstrated that longer intervals between feedings are nonviable, causing death and cannibalism. The quantity of food is calculated according to the quantity of scorpions in each cage; a roach for every two animals, or an adult cricket for every animal (figure 4).

\section{Venom Extraction}

Extraction is performed every month, following a chronogram, which in relation to the feeding, trying to answer the necessities of the Production Division. This division sent to the Laboratory of Arthropod an annual immunization chronogram for serum production, containing the necessary quantity of scorpion venom (figure 5).

Food is given a week after venom extraction in order to allowing time for the animals to recover from stress. If they are fed before the extraction, the quantity of venom produced can be affected.

Right now, only Tityus serrulatus venom is included in the composition of the antiarachnidic and anti-scorpion serum because it shows a crossed activity against other species, which cause frequent accidents, such as Tityus bahiensis and Tityus stigmurus (1).

The equipment for venom extraction was developed in 1996 in collaboration which SENAI "Roberto Simonsen" (a technical school of São Paulo city). It aims to better profit from animals, reducing the negative effects caused by shock. This equipment was named "Arthropods Electronic Stimulator" (figure 6). It is an electronic equipment that produce a high frequency of electrical stimulus, modulated by low adjustable frequency (values among 0,5-2 Hz), with low intensity and high voltage, with control and adjust systems, designed to stimulate the venom glands by electrodes, with low damage and risk. It has an adjust system of exposition between 0 $\mathrm{V}$ and $1700 \mathrm{~V}_{\mathrm{pp}}$ (top voltage and top). This equipment allowed to determining the ideal intensity of stimulus to be applied to the animals. For first venom extraction, scorpions submitted to a $1,250 \mathrm{kV}$ electrical stimulus at a frequency of $0,5 \mathrm{~Hz}$, which 
D. M. Candido; S. Lucas. MAINTENANCE OF SCORPIONS OF THE GENUS Tityus KOCH (SCORPIONES, BUTHIDAE) FOR VENOM OBTENTION AT INSTITUTO BUTANTAN, SÃO PAULO, BRAZIL. J. Venom. Anim. Toxins incl. Trop. Dis., 2004, 10, 1, p.92.

yielded an average of $0.4 \mathrm{mg}$ of venom from each animal. From the second and wards subsequent extraction, the average quantity of venom is gradually reduced (table 2). Venom obtained over the month is dried by liophilization.

Table 2. Venom extraction carried out between January 2001 and July 2002 with a 3 month interval, using the equipament developed by SENAI.

\begin{tabular}{c|c|c|c|c|c|c|c}
\hline Poison extractions & $1^{\mathrm{a}}$ & $2^{\mathrm{a}}$ & $3^{\mathrm{a}}$ & $4^{\mathrm{a}}$ & $5^{\mathrm{a}}$ & $6^{\mathrm{a}}$ & $7^{\mathrm{a}}$ \\
\hline Number of specimens & 291 & 204 & 136 & 125 & 109 & 52 & 13 \\
Average quantity of poison & 0,42 & 0,36 & 0,24 & 0,24 & 0,23 & 0,17 & 0,13 \\
$(\mathrm{mg})$ & & & & & & & \\
\hline
\end{tabular}

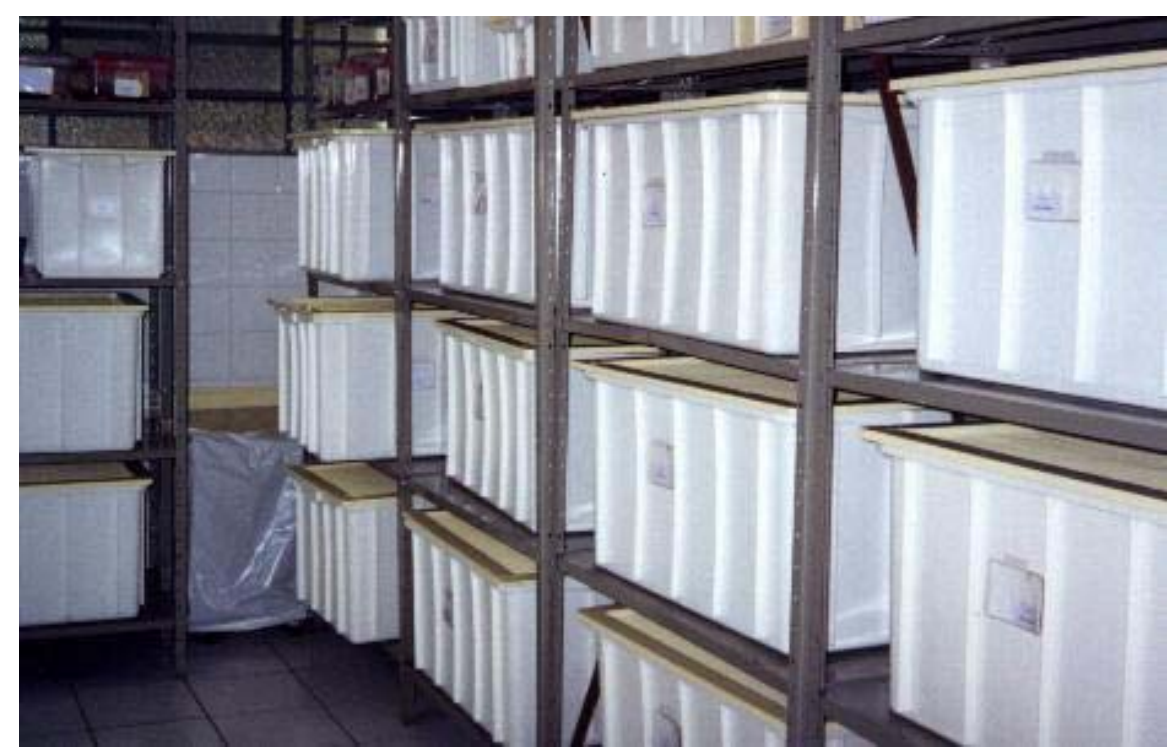

Figure 1. The bioterium of scorpions of the Laboratory of Arthropods at Instituto Butantan. D. M. Candido. 
D. M. Candido; S. Lucas. MAINTENANCE OF SCORPIONS OF THE GENUS Tityus KOCH (SCORPIONES, BUTHIDAE) FOR VENOM OBTENTION AT INSTITUTO BUTANTAN, SÃO PAULO, BRAZIL. J. Venom. Anim. Toxins incl. Trop. Dis., 2004, 10, 1, p.93.

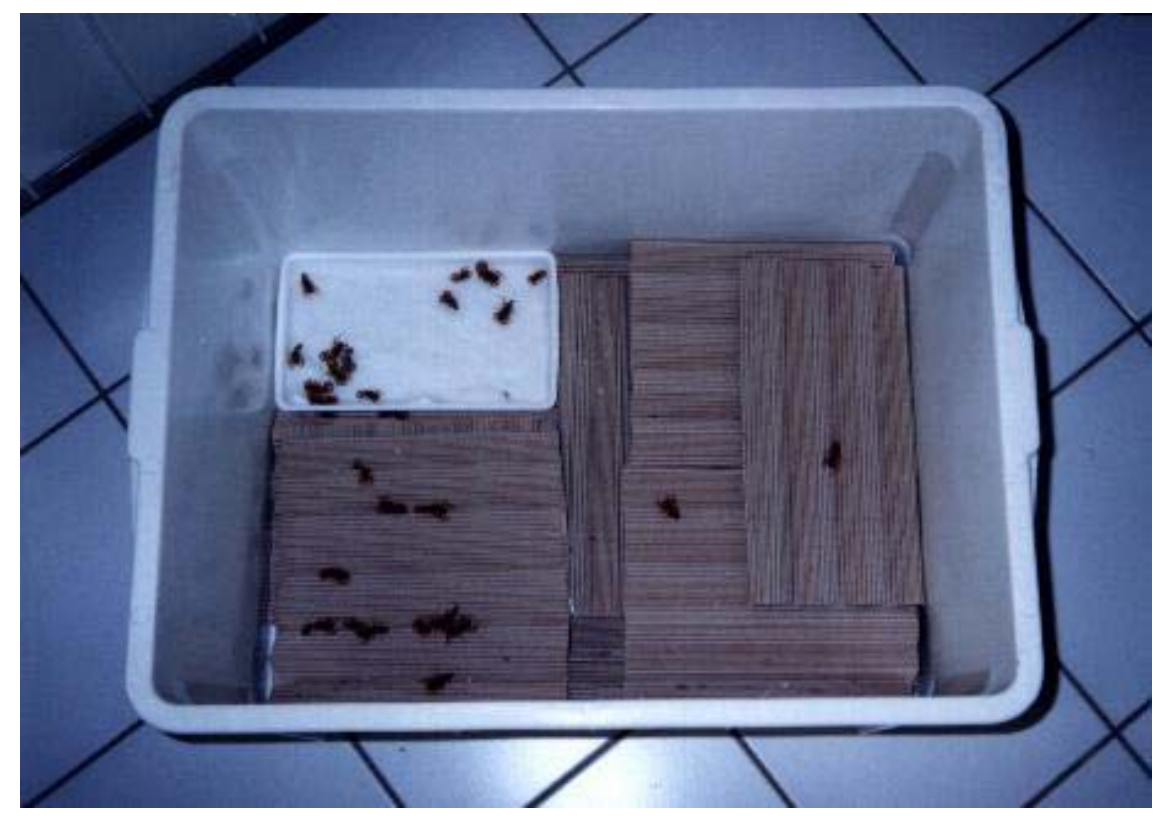

Figure 2. The scorpion's box. D. M. Candido.

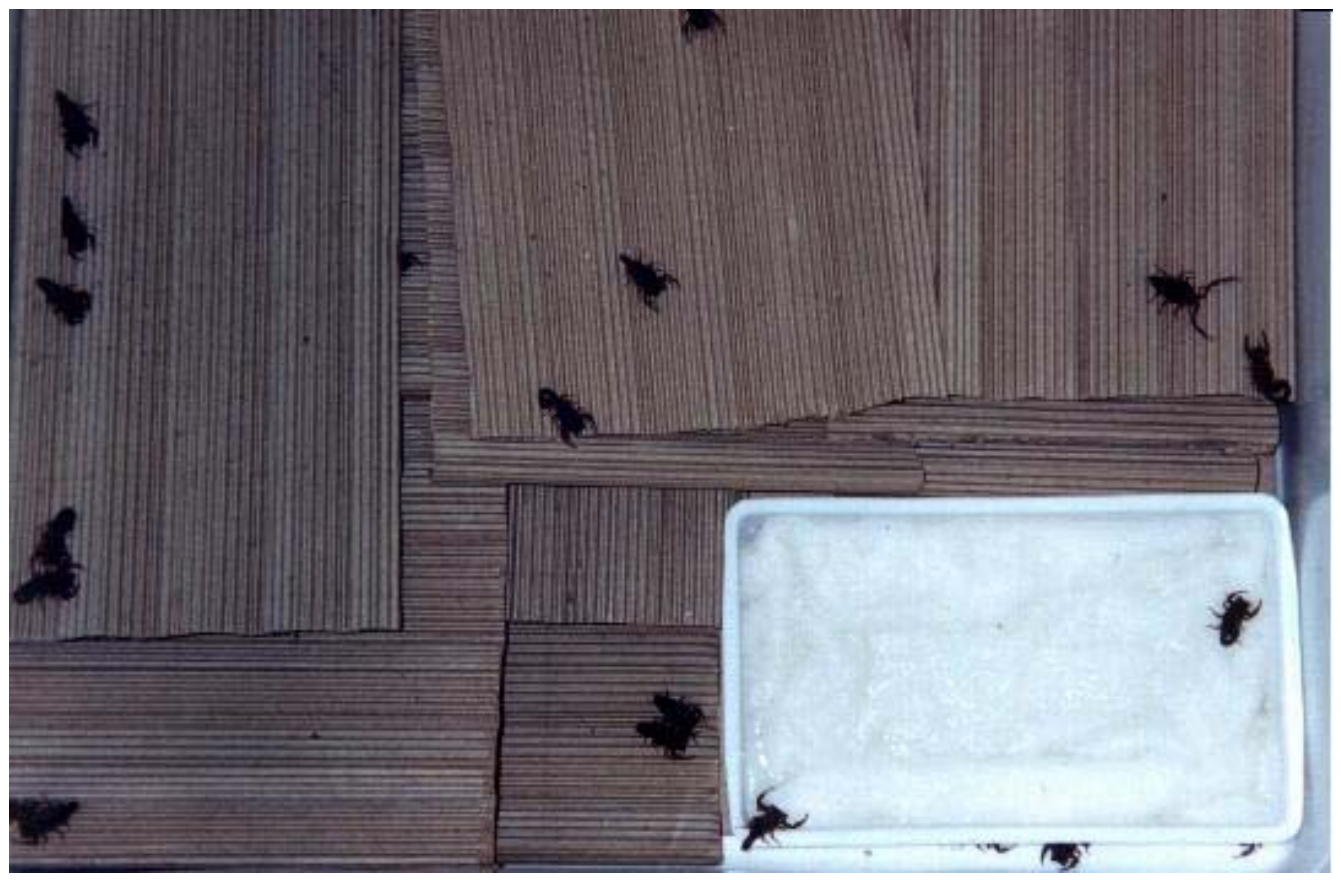

Figure 3. The scorpion's box. D. M. Candido. 
D. M. Candido; S. Lucas. MAINTENANCE OF SCORPIONS OF THE GENUS Tityus KOCH (SCORPIONES, BUTHIDAE) FOR VENOM OBTENTION AT INSTITUTO BUTANTAN, SÃO PAULO, BRAZIL. J. Venom. Anim. Toxins incl. Trop. Dis., 2004, 10, 1, p.94.

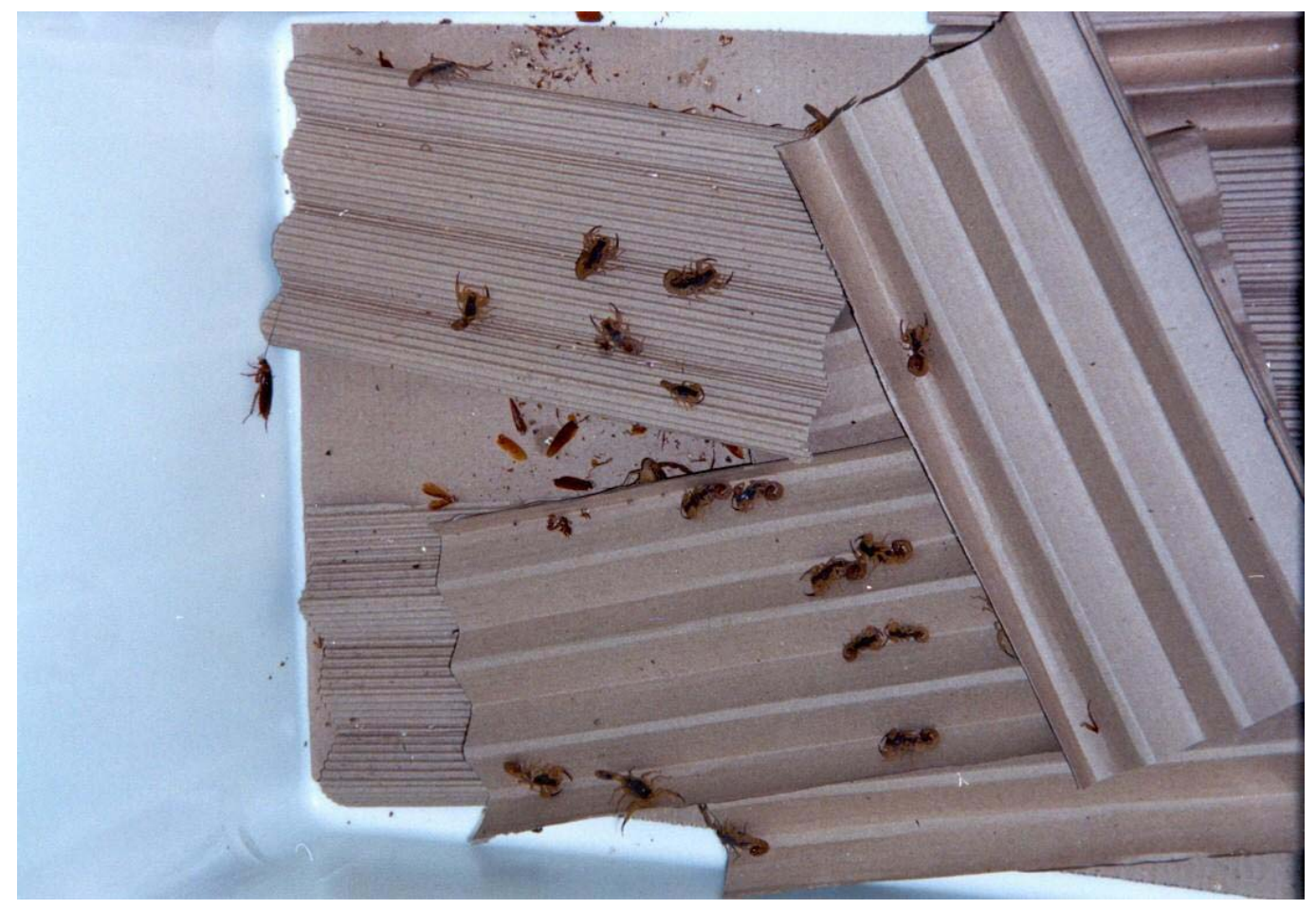

Figure 4. Feeding with Periplaneta americana. D. M. Candido.

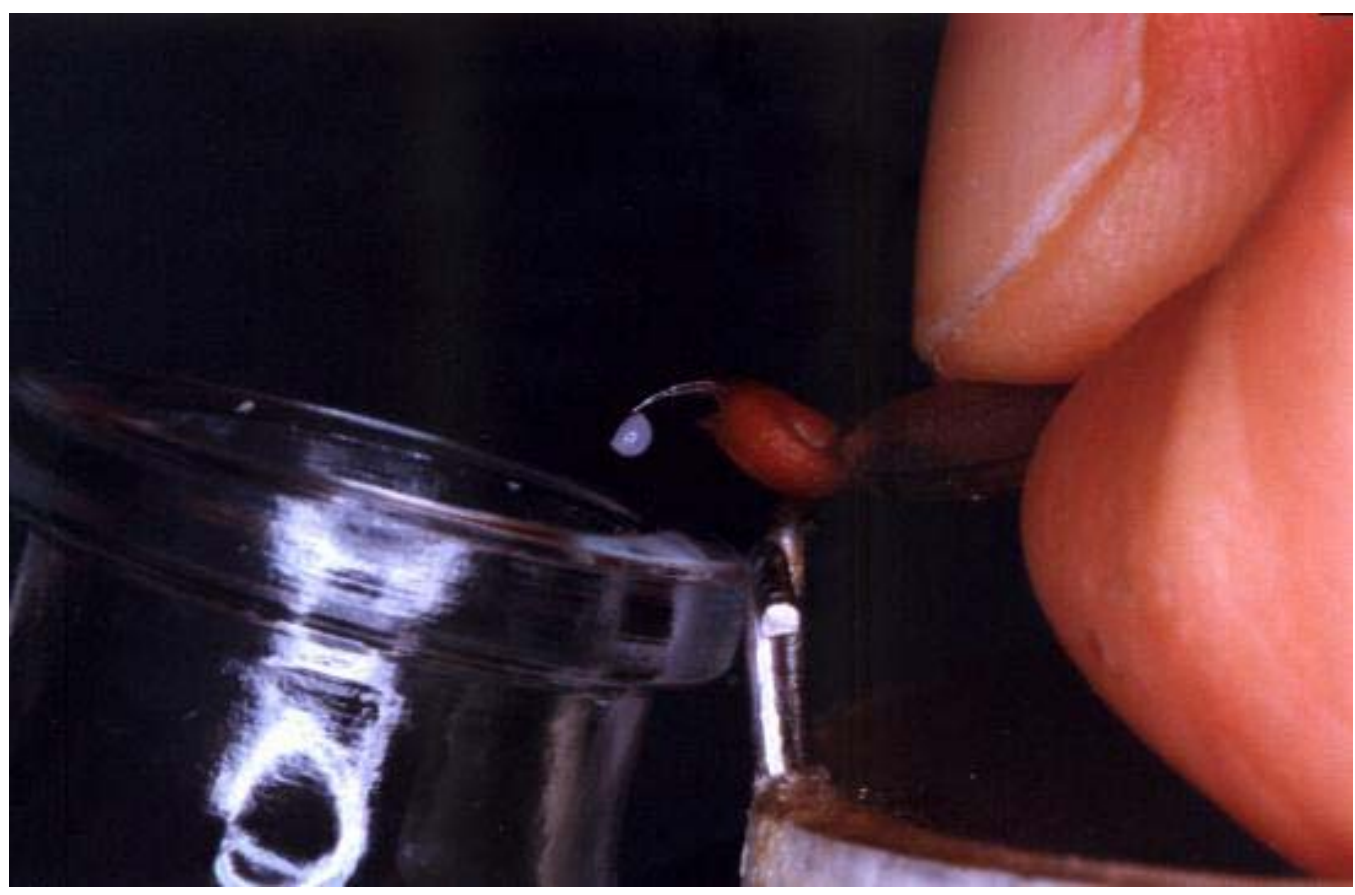

Figure 5. Venom extraction. J. L. D. Latuffi. 


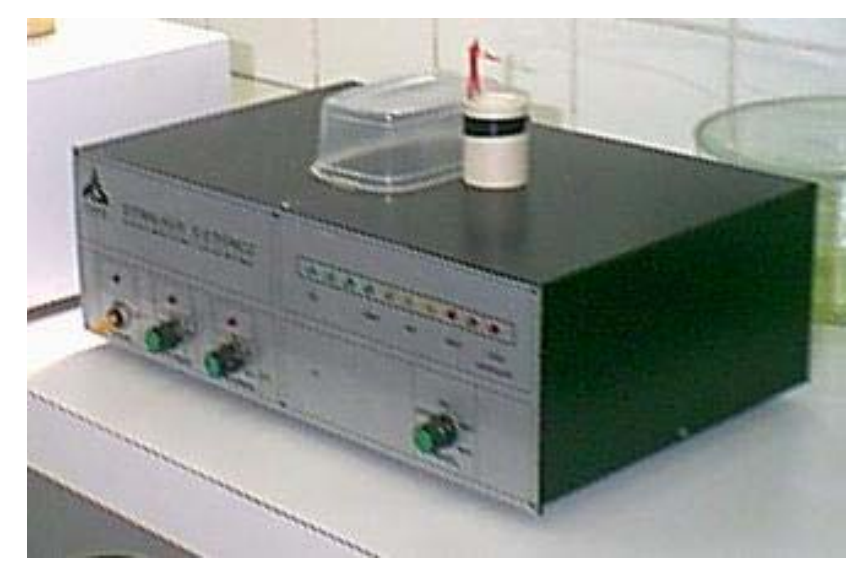

Figure 6. The equipment used for venom extraction. R. P. Indicatti.

\section{CONCLUSIONS}

The success of a maintenance of scorpions in order to obtain venom, depends on several factors, such as: the collection of animals from their natural habitat during seasons of high occurrence, and in locations of confirmed existence of scorpions; voluntary donation depends on stimulus such as campaigns and lectures to encourage people to catching and sending animals, communication between institutions, etc. These stimuli must be periodical to guarantee supply continuity; a laboratory supervisor is important to organize feed and venom extraction, control of animals per cage and in captivity; maintaining temperature room above $20^{\circ} \mathrm{C}$, and other laboratory activities. Heating is necessary just in places with colder winter; the quantity of animals kept in a bioterium depends on its size, and food availability, and it must be appropriate to the production target; the quantity of animals in each cage depends directly on size of the cage; the substrate used in each must be adapted to avoid stress and cannibalism, and offer comfort for them; the introduction of an insect house to feed scorpions is very important, because it is not possible to offer food of unknown origin in order to avoiding contamination and loss of scorpions; food must be offered periodically with intervals no longer than forty days, supplying, at least, a cricket for each scorpion, or a roach for every two scorpions; feed must be offered one week after venom extraction to guarantee better animal recovery, assuring the animal hunts 
D. M. Candido; S. Lucas. MAINTENANCE OF SCORPIONS OF THE GENUS Tityus KOCH (SCORPIONES, BUTHIDAE) FOR VENOM OBTENTION AT INSTITUTO BUTANTAN, SÃO PAULO, BRAZIL. J. Venom. Anim. Toxins incl. Trop. Dis., 2004, 10, 1, p.96.

alive food, because the animal rarely feeds of dead insects; cleaning of cages should be rigorous and weekly, avoiding the use of aggressive products; handling of animals must be reduced to a minimum and done with long metal tongs, measuring from 20 to $30 \mathrm{~cm}$ to preventing accidents; the interval between venom extractions must be at least 30 days to guarantee an appropriate venom production and to permit a minimum rest period for each animal. According to experience, a longer interval between venom extractions results in a better yield; electrical stimulus applied to the animal must be controlled to guarantee animal survival and continuous profit; permanence of animals in a bioterium depends on factors such as a continuous supply, permitting the death of older and/or weaker scorpions since there are enough animals to give continuity to production.

\section{ACKNOWLEDGMENTS}

We are very grateful to Rosana Nunes dos Santos for the English review and help us with the specification of electronic equipament .

\section{REFERENCES}

1 BECERRIL B., MARANGONI S., POSSANI LD. Toxins and genes isolated from scorpions of the genus Tityus. Toxicon, 1997, 35, 6, 821-35.

2 BRAZIL V. Soro Anti-Escorpiônico. Mem. Inst. Butantan, 1918, 1, 47-52.

3 BÜCHERL W. Escorpiões e Escorpionismo no Brasil. 1. Manutenção dos escorpiões em viveiros e extração de venenos. Mem. Inst. Butantan, 1953, 25, $1,53-82$.

4 BUCHERL W. Escorpionismo no Brasil. Mem. Inst. Butantan, 1969, 34, 9-24.

5 EICKSTEDT VRD. von, RIBEIRO LA., CANDIDO DM., ALBUQUERQUE MJ., JORGE MT. Evolution of scorpionism by Tityus bahiensis (Perty) and Tityus serrulatus (Lutz and Mello) and geographical distribuition of the two species in the state of São Paulo - Brazil. J. Venom. Anim. Toxins, 1996, 2, 92-105. $(\underline{\operatorname{SciELO}})$ 
D. M. Candido; S. Lucas. MAINTENANCE OF SCORPIONS OF THE GENUS Tityus KOCH (SCORPIONES, BUTHIDAE) FOR VENOM OBTENTION AT INSTITUTO BUTANTAN, SÃO PAULO, BRAZIL. J. Venom. Anim. Toxins incl. Trop. Dis., 2004, 10, 1, p.97.

6 MAURANO HR. O Escorpionismo. Rio de Janeiro: Universidade Federal do Rio de Janeiro, Faculdade de Medicina, 1915. 268p. [tese-doutorado].

7 SECRETARIA DE ESTADO DA SAÚDE DE SÃO PAULO. SUPERINTENDÊNCIA DE CONTROLE DE ENDEMIAS (SUCEN). CENTRO DE VIGILÂNCIA EPIDEMIOLÓGICA (CVE). INSTITUTO BUTANTAN. Manual de Diretrizes Para Atividades de Controle de escorpiões. São Paulo, 1994. 48p. 